\title{
HAKIKAT MANUSIA, ALAM SEMESTA, DAN MASYARAKAT DALAM KONTEKS PENDIDIKAN ISLAM
}

\author{
Alimatus Sa'diyah Alim \\ Universitas Islam Negeri (UIN) Sunan Kalijaga Yogyakarta \\ e-mail: indeluinsuka@gmail.com
}

\begin{abstract}
Abstrak: Tujuan dari penelitian ini adalah untuk mengetahui esensi manusia, alam semesta, dan masyarakat dalam perspektif filsafat pendidikan Islam. Penelitian ini menggunakan metode penelitian pustaka, yakni peneliti menganalisis literatur tertulis sebagai sumber utama. Hasil penelitian ini menunjukkan bahwa menusia memiliki keunggulan dari makhluk lain di alam semesta. Eksistensinya sebagai 'abdullah sekaligus sebagai kbalifatullah di bumi. Manusia sebagai hamba ('abdullab) memiliki inspirasi nilai-nilai ketuhanan yang tertanam sebagai pejalan amanah (khalifah) Tuhan dimuka bumi. Keingintahuan manusia menjadikannya bersifat kreatif dengan disemangati nilai-nilai trasendensi. Manusia dengan manusia lainnya memiliki korelasi yang seimbang, tolong menolong (ta'awun), dan saling bekerja sama dalam rangka memakmurkan bumi. Manusia dengan alam sekitar merupakan sarana untuk meningkatkan pengetahuan, rasa syukur, dan mendekatkan diri kepada tuhan.
\end{abstract}

Kata kunci: manusia, maysarakat, pendidikan Islam

Title: Human Essence, Universe, and Community in Islamic Education Perspective

Abstract: The purpose of this research is to find out how the perspective of Islamic education philosophy relates to the buman essence, the universe, and society. The research method uses library research, in which the researcher analyzes written literature as the main source. The results of this study indicate that humans have advantages over other creatures in the universe. The existence of human as servants ('abdullah) as well as caliph of Allah (khalifatullah) on earth. Humans as 'abdullah have inspired the divine values. Human curiosity makes it creative by encouraging transcendence values. Human curiosity makes it creative by encouraging values of transcendence. Humans with other humans have a balanced correlation, please help (ta'awnu), and cooperate with each other in order to prosper the earth. Humans with the natural surroundings is a means to increase knowledge, gratitude, and a means to get closer to God.

Keywords: buman, society, Islamic education

DOI: https://doi.org/10.20414/jpk.v15i2.1760 


\section{PENDAHULUAN}

Manusia dalam jagad raya ini adalah makhluk yang unik, keunikannya sangat menarik dimata manusia sendiri, yaitu yang mendasari perbedaan manusia dengan makhluk-makhluk Allah lainnya adalah Allah memuliakan manusia dengan memberi akal, sedangkan mahluk Allah yang lain tidak diberikan, disitulah kemuliaan manusia dibandingkan dengan makhluk lainnya. sehingga banyak kajian-kajian tentang manusia yang terus berkembang karena pengetahuan manusia tentang dirinya terbatas. Untuk menjawab permasalahan tersebut, Alqur`an telah banyak menjelaskan berbagai hal yang berkaitan dengan manusia. ${ }^{1}$

Manusia adalah satu jenis makhluk hidup yang jadi anggota populasi permukaan bumi ini. Ia adalah satu himpunan yang mempunyai ciri khas tersendiri yang tidak dimiliki oleh sekian juta makhluk hidup lainnya. Manusia selama ia hidup selalu berusaha dan berjuang untuk memanfaatkan alam sekitarnya dengan cara menggunakan daya dan tenaga alam, untuk kepentingan dirinya. ${ }^{2}$

Disatu sisi lain, bahwa manusia tidak bisa hidup sendirian, karena manusia disebut sebagai makhluk sosial yang selalu ketergantungan kepada orang lain. Disamping manusia bergantung kepada manusia lain, juga karakteristik manusia itu adalah berkemampuan menyesuaikan diri (adaptability) dengan kondisi lingkungan yang dihadapi. ${ }^{3}$

Manusia, masyarakat, dan alam semesta merupakan tiga hal yang saling berhubungan erat dan tidak bisa terpisahkan satu sama lain. Karena manusia diciptakan Allah sebagai khalifah di alam semesta, tetapi manusia tidak akan mampu hidup sendiri, karena manusia disebut sebagai makhluk sosial yang saling ketergantungan satu sama lain. Sedangkan ilmu pengetahuan merupakan hasil dari pemikiran manusia yang selalu digunakan untuk menyingkap tabir ketidaktahuan dan mencari solusi kehidupan. Karena manusia merupakan subyek utama dalam ilmu pengetahuan.

\section{METODOLOGI PENELITIAN}

Jenis penelitian ini adalah library research, yakni penelitian yang dilakukan dengan menganalisis dan menjadikan literatur tertulis berupa buku, jurnal ilmiah maupun surat kabar sebagai sumber utama. Penelitian ini bersifat kualitatif, yakni penelitian yang menekankan pada analisis terhadap data-data yang sudah ada sebelumnya.

Metode yang digunakan dalam penelitian ini adalah deskriptif analisis. Metode deskriptif analisis digunakan untuk memaparkan bagaimana hakikat manusia, alam semesta dan masyarakat dalam perspektif pendidikan Islam. Serta hubungannya dengan

\footnotetext{
${ }^{1}$ Anwar Sutoyo, Manusia Dalam Perspektif Alqur'an, (Yogyakarta: Pustaka Pelajar) h. 2

${ }^{2}$ H.M. Djumberansjah Indar, Filsafat Pendidikan, ( Surabaya : Karya Abditama,1994) h. 75

${ }^{3}$ Maragustam, Filsafat Pendidikan Islam, (Yogyakarta : Kurnia Kalam Semesta, 2014) h. 82
} 
fenomena yang dianalisis. Kemudian data-data tesebut di analisis untuk mendapatkan penjelasan tentang implikasi hakikat manusia, alam semesta dan masyarakat dalam perspektif pendidikan Islam.

\section{HASIL DAN PEMBAHASAN}

\section{Hakikat Manusia Dalam Al-Qur`an}

M. Quraish Shihab menunjukkan ada tiga kata yang digunakan Al-Qur`an dalam menyebut "manusia".

1. Basyar

Penggunaan istilah "basyar" dalam al-qur`an lebih cenderung digunakan pada hal-hal yang berkaitan dengan aspek fisik yang tampak pada manusia secara umum (seperti : kulit, rambut, bentuk fisik secara umum, dan kebutuhan biologis) yang tidak berbeda diantara manusia satu dengan yang lainnya. Dalam beberapa kasus istilah basyar juga digunakan untuk menggambarkan aspek-aspek psikis seperti kebutuhan, batas-batas kemampuan mengindera (melihat hal-hal yang ghaib), aktivitas belajar ( mendapatkan ilmu yang hanya diajarkan oleh Allah), dan tahap-tahap perkembangkan manusia hingga mencapai kedewasaan. Dengan kata lain istilah basyar lebih banyak menggambarkan persamaan yang ada pada semua manusia, baik dalam aspek fisik maupun psikis. Sebagaimana firman Allah dalam surah al-Ruum (30) ayat 20:

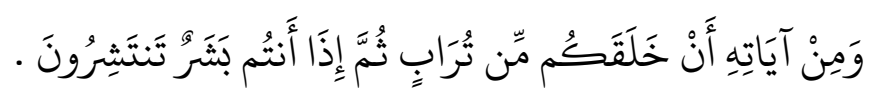

Dan di antara tanda-tanda kekuasaan-Nya ialah Dia menciptakan kamu dari tanah, kemudian tiba-tiba kamu (menjadi) manusia yang berkembang biak.4

2. Kata-kata yang terdiri dari alif, nun, dan, sin

Semacam Insan, Ins, Nas atau Unas, Kata Insan menurut Ibnu Manzhur (2002, I : 231) berasal dari kata "Insiyan". Yang berarti manusia ( kecil ), sedangkan menurut M.Quraish Shihab (2000: 280) istilah Insan terambil dari kata "Uns" yang berarti jinak, harmonis, dan tampak. Jinaknya manusia (normal) ini lebih tampak manakala dibandingkan dengan binatang seperti harimau, serigala, ular, dan binatang buas lainnya. Kata Insan dalam al-qur an digunakan untuk menunjuk manusia dengan seluruh totalitasnya, yaitu jiwa dan raganya. Perbedaan manusia antara satu dengan yang lainnya adalah karena perbedaan fisik, dan kecerdasan, menggambarkan perbedaan-perbedaan dalam aspek kerohanian, keimanan, dan akhlak. Dengan kata lain Insan disamping digunakan untuk menunjuk manusia secara utuh, juga menggambarkan perbedaan antara seseorang dengan lainnya.

\footnotetext{
${ }^{4}$ Departemen Agama RI, Alqur an dan Terjemahannya, (Bandung: PT Sygma Examedia Arkanleema) h. 406
} 
3. Bani Adam dan zuriyah Adam

Kata "Dzurriyyah menurut Ibnu Manzhur (1996, V: 42) berkaitan dengan keturunan, jika dikatakan "Inna Fulanan La Kariimu Adz-Dzurry” maknanya adalah "Karimu Ath-Thabi Ab” (pembawaannya sejak lahir mulia). Dzuriyyah juga berkaitan dengan sesuatu yang jatuh (diperoleh) anak dari orang tuanya bila kata Dzuriyyah dikaitkan dengan Adam lebih menggambarkan keturunan dari mana seseorang berasal, dan sifat-sifat bawaannya yang dibawa sejak lahir. Dari keterangan ini tampak pula, bahwa semua makhluk yang tergolong manusia di jagad raya ini berasal dari induk yang sama yaitu pasangan Nabi Adam dan Hawa. Dari sini tampak pula, bahwa ada sifat-sifat bawaan yang kurang lebih sama diwariskan secara turun temurun melalui proses perkawinan sejak dari zaman Nabi Adam hingga sekarang.

Manusia dalam pandangan Al-Qur`an, manusia sebagai makhluk yang berdimensional memiliki kedudukan yang sangat mulia. Tetapi sebelum membahas tentang kedudukan perlu diketahui tentang esensi dan eksistensi manusia. Manusia memiliki eksistensi dalam hidupnya sebagai abdullah dan khalifah sebagai utusan Allah dimuka bumi, disini harus bersentuhan dengan sejarah dengan mengembangkan esensi ingin tahu menjadikan ia bersifat kreatif dengan disemangati dengan nilai-nilai trasendensi. Manusia dengan tuhan memiliki kedudukan sebagai hamba, yang memiliki inspirasi nilainilai ketuhanan yang tertanam sebagai pejalan amanah tuhan dimuka bumi. Manusia dengan manusia lainnya memiliki korelasi yang seimbang dan saling bekerja sama dalam rangka memakmurkan bumi. Manusia dengan alam sekitar merupakan sarana untuk meningkatkan pengetahuan dan rasa syukur kita terhadap tuhan dan bertugas menjadikan alam sebagai subyek dalam rangka mendekatkan diri kepada tuhan. ${ }^{5}$

Manusia Sebagai Khalifah di Muka Bumi. Coba kita perhatikan dialog antara Allah dengan para malaikat ketika hendak menciptakan manusia yang pertama yaitu Nabi Adam As. Yang diabadikan Allah dalam surah al-Baqarah (2) ayat 30:

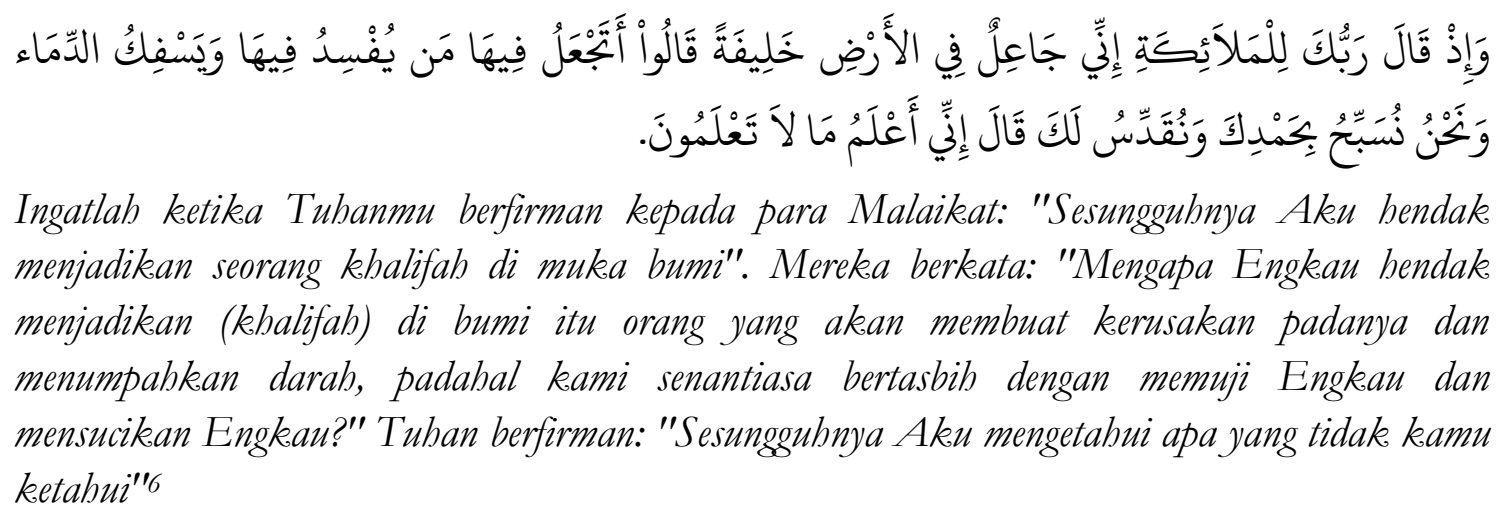

Ingatlah ketika Tuhanmu berfirman kepada para Malaikat: "Sesunggubnya Aku hendak menjadikan seorang khalifah di muka bumi". Mereka berkata: "Mengapa Engkau hendak menjadikan (khalifah) di bumi itu orang yang akan membuat kerusakan padanya dan menumpabkan darah, padahal kami senantiasa bertasbih dengan memuji Engkau dan mensucikan Engkau?" Tuban berfirman: "Sesungguhnya Aku mengetahui apa yang tidak kamu ketabui"6

\footnotetext{
${ }^{5}$ Anwar Sutoyo, Manusia Dalam Perspektif Alqur an, (Yogyakarta : Pustaka Pelajar) h. 40

${ }^{6}$ Departemen Agama RI, Alqur’an dan Terjemahannya, (Bandung: PTSygma Examedia Arkanleema) h. 6
} 
M. Quraish Shihab dalam menafsirkan kata khalifah pada ayat diatas menjelaskan, bahwa kata "khalifah pada mulanya berarti yang menggantikan atau ada yang datang sesudah siapa yang datang sebelumnya. Atas dasar ini, ada yang memahami kata khalifah disini dalam arti yang menggantikan Allah dalam menegakkan kehendaknya dan menerapkan ketetapan-ketetapannya. Tetapi hal ini tidak berarti bahwa Allah tidak mampu, atau menjadikan manusia berkedudukan sebagai tuhan. Tidak! Allah bermaksud dengan pengangkatan itu untuk menguji manusia dan memberinya penghormatan. Jadi esensi tujuan penciptaan manusia adalah Allah hendak memberi tugas kepada manusia sebagai khalifah Allah di bumi, yaitu melaksanakan amanah sesuai tuntunan Allah dan rasulnya dalam bidang ke ablian atau kewenangan sesuai yang dikaruniakan Allah kepadanya.

Beranjak dari permasalahan bahwa ada dua unsur sehubungan dengan makna khalifah, yakni unsur internal (yang mengarah kepada hubungan horizontal) yang berkaitan dengan manusia, alam raya dan antar manusia dengan alam raya.

Dalam hubungan horizontal ini mengarah kepada hubungan manusia dengan manusia lainnya, dan hubungan dengan alam raya, bahwa Allah telah memberikan kehidupan di dunia sehingga berusaha dan semua dari usaha itu dijadikan sebagai ibadah kepada Allah, karena Allah tidak melarang manusia untuk bekerja, bahkan tidak hanya memikirkan akhirat saja, namun antara kesimbangan antara dunia dan akhirat. ${ }^{7}$ Firman Allah dalam Surah Qashashas (28) ayat 77:

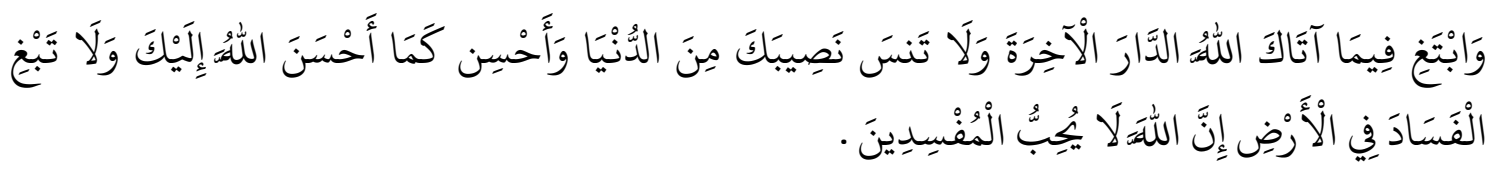

Dan carilah pada apa yang telah dianugerabkan Allah kepadamu (kebahagiaan) negeri akbirat, dan janganlah kamu melupakan bahagianmu dari (kenikematan) duniawi dan berbuat baiklah (kepada orang lain) sebagaimana Allah telah berbuat baik, kepadamu, dan janganlah kamu berbuat kerusakan di (muka) bumi. Sesunggubnya Allab tidak menyukai orang-orang yang berbuat kerusakan. ${ }^{8}$

Dan yang kedua unsur eksternal (kaitannya dengan hubungan vertical) yaitu penugasan Allah kepada manusia sebagai mandatasis Allah dan pada hakekatnya eksistensi manusia dalam kehidupan ini adalah membangun dan mengelola dunia tempat hidupnya ini sesuai dengan kehendak penciptaannya. Tugas kekhalifahan tersebut memang sangat berat. Namun status ini menunjukkan arah peran manusia sebagai penguasa di bumi atas petunjuk Allah.

Abdul Allah (Hamba Allah) Dalam konteks konsep abdullah Allah, manusia harus menyadari betul akan dirinya sebagai abdi, hal ini berarti bahwa manusia harus

${ }^{7}$ Anwar Sutoyo, Manusia Dalam Perspektif Alqur an, ( Yogyakarta : Pustaka Pelajar) h. 87

8 Departemen Agama RI, Alqur an dan Terjemahannya, (Bandung: PTSygma Examedia Arkanleema) h. 385 
menempatkan dirinya sebagai yang dimiliki, tunduk dan taan kepada semua ketentuan Allah. Kedudukan sebagai hamba Allah ini memang menjadi tujuan Allah menciptakan manusia dan makhluk-makhluk lainnya yang artinya manusia berkewajiban memaknai semua usaha dan kegiatannya sebagai ihktiar dan realisasi penghambaan diri kepada Allah termasuk melalui aktivitas pengelolaan alam raya dengan berkuasa yang dimilikinya, guna memenuhi kebutuhan hidup. Untuk lebih jelasnya kita lihat. firman Allah dalam surah al-Dzariyat (51) ayat 56:

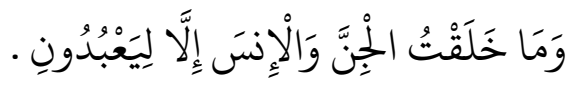

Dan aku tidak menciptakan jin dan manusia melainkan supaya mereka menyembabku (mengabdi kepada-Ku).

M. Quraish Shihab dalam menafsirkan Liya`Buduun pada ayat diatas menjelaskan, bahwa bukan berarti agar supaya mereka itu beribadah, atau agar Allah disembah. Pemaknaan seperti ini di pandang mustahil sebab Allah tidak membutuhkan sesuatu. Dari sini bisa dipahami, bahwa tujuan penciptaan manusia itu bukan untuk Allah, tetapi untuk diri manusia itu sendiri. Jadi bila dalam ayat tersebut dikatakan agar manusia beribadah, maka manfaat ibadah yang dilakukan manusia itu bukan untuk Allah melainkan untuk manusia itu sendiri.

Tujuan diciptakan manusia sebagai khalifah Allah di bumi dan sekaligus beribadah kepadanya, dan bukan untuk Allah, melainkan untuk diri sendiri, artinya jika amanah yang dibebankan kepada manusia dan atau ibadah yang harus dilaksanakan manusia itu dilaksanakan sesuai tuntunan Allah, niscaya manfaatnya untuk diri sendiri bukan untuk Allah, seperti manusia dilarang minum minuman yang memabukkan. Keuntungan dari mematuhi larangan tersebut adalah untuk manusia itu sendiri bukan untuk Allah. ${ }^{9}$

\section{Aliran Filsafat Islam Tentang Manusia}

Setidaknya terdapat empat aliran pemikiran yang berkaitan tentang masalah rohani dan jasmani (sudut pandang unsur pembentuk manusia) yaitu: Aliran serba zat, aliran serba ruh, aliran dualisme, dan aliran eksistensialisme.

1. Aliran Serba Zat (Faham Materialisme)

Aliran serba zat ini mengatakan yang sungguh-sunguh ada itu adalah zat atau materi, alam ini adalah zat atau materi dan manusia adalah unsur dari alam, maka dari itu manusia adalah zat atau materi. Manusia ialah apa yang nampak sebagai wujudnya, terdiri atas zat (darah, daging, tulang).

Jadi, aliran ini lebih berpemahaman bahwa esensi manusia adalah lebih kepada zat atau materinya. Manusia bergerak menggunakan organ, makan dengan tangan,

\footnotetext{
${ }_{9}$ Anwar Sutoyo, Manusia Dalam Perspektif Alqur'an, (Yogyakarta : Pustaka Pelajar) h. 8
} 
berjalan dengan kaki, dll. Semua serba zat atau meteri. Berdasar aliran ini, maka dalam pendidikan manusia harus melalui proses mengalami atau pratek (psikomotor).

2. Aliran Serba Ruh

Dalam buku lain, aliran ini diberi nama Aliran Idealisme. Aliran ini berpendapat bahwa segala hakikat sesuatu yang ada di dunia ini adalah ruh, juga hakekat manusia adalah ruh.Ruh disini bisa diartikan juga sebagai jiwa, mental, juga rasio/akal. Karena itu, jasmani atau tubuh (materi, zat) merupakan alat jiwa untuk melaksanakan tujuan, keinginan dan dorongan jiwa (rohani, spirit, ratio) manusia.

Jadi, aliran ini beranggapan bahwa yang menggerakkan tubuh itu adalah ruh atau jiwa. Tanpa ruh atau jiwa maka jasmani, raga atau fisik manusia akan mati, sia-sia dan tidak berdaya sama sekali. Dalam pendidikan, maka tidak hanya aspek pengalaman saja yang diutamakan, faktor dalam seperti potensi bawaan (intelegensi, rasio, kemauan dan perasaan) memerlukan perhatian juga.

3. Aliran Dualisme

Aliran ini menganggap bahwa manusia itu pada hakekatnya terdiri dari dua substansi, yaitu jasmani dan rohani. Aliran ini melihat realita semesta sebagai sintesa kedua kategori animate dan inanimate, makhluk hidup dan benda mati. Demikian pula manusia merupakan kesatuan rohani dan jasmani, jiwa dan raga.

Misalnya ada persoalan: dimana letaknya mind (jiwa, rasio) dalam pribadi manusia. Mungkin jawaban umum akan menyatakan bahwa ratio itu terletak pada otak. Akan tetapi akan timbul problem, bagaiman mungkin suatu immaterial entity (sesuatu yang non-meterial) yang tiada membutuhkan ruang, dapat ditempatkan pada suatu materi (tubuh jasmani) yang berada pada ruang wadah tertentu.

Jadi, aliran ini meyakini bahwa sesungguhnya manusia tidak dapat dipisahkan antara zat/raga dan ruh/jiwa. Karena pada hakekatnya keduanya tidak dapat dipisahkan. Masing-masing memiliki peranan yang sama-sama sangat vital. Jiwa tanpa ruh ia akan mati, ruh tanpa jiwa ia tidak dapat berbuat apa-apa. Dalam pendidikan pun, harus memaksimalkan kedua unsur ini, tidak hanya salah satu saja karena keduanya sangat penting.

4. Aliran Eksistensialisme

Aliran filsafat modern berpikir tentang hakekat manusia merupakan eksistensi atau perwujudan sesungguhnya dari manusia. Jadi intinya hakikat manusia itu yaitu apa yang menguasai manusia secara menyeluruh. Disini manusia dipandang dari serba zat, 
serba ruh atau dualisme dari kedua aliran itu, tetapi memandangnya dari segi eksistensi manusia itu sendiri di dunia. ${ }^{10}$

\section{Hakikat Alam Semesta}

\section{Pengertian Alam Semesta}

Menurut sejarah filsafat, filsafat yang pertama lahir adalah filsafat alam. Filsafat ini adalah filsafat Yunani yang digarab oleh orang-orang Yunani, tapi bukan didaerah Yunani sendiri. Filsafat ini dicetuskan oleh orang-orang Yunani perantauan yang mengembara ke negeri lain, terutama Asia kecil. Dari sebuah Kota bernama Miletos di Asia Kecil, lahirlah filsafat alam pertama yang dicetuskan oleh ahli filsafat pertama yang bernama Thales yang menyatakan bahwa asal segala sesuatu adalah air. Kemudian filsafat ini dilanjutkan oleh muridnya, Anaxi Mandos yang menyebutkan bahwa awal dari segala sesuatu adalah Apeiron, yaitu suatu zat yang tidak terbatas, dan dilanjutkan juga dengan muridnya Anaximenes, yang berpendirian bahwa asal-usul alam semesta ini adalah udara. Dari kota Miletos inilah, filsafat alam menyebar ke kota-kota lain seperti Ephesos dan tokohnya Herakleitos dan kota Elea dengan tokohnya Xenophanes, dan Zero. Demikianlah seterusnya hingga muncul Plato dengan filsafat Idealisme dan Aristoteles dengan Realisme. ${ }^{11}$

Sejarah lahirnya filsafat pendidikan tentang alam diawali oleh banyaknya pertanyaan yang muncul dari para filsuf Yunani tentang keberadaan alam ini. Thales misalnya, yang melihat air dan memandang segala sesuatu berasal dari air, berpendapat bahwa alam ini berasal dari air. Einstein merumuskan persamaan matematis pada tahun 1917, yang diharapkan dapat melukiskan sifat dan kelakuan alam semesta. Ia melukiskan alam bersifat statis, tetapi ia gagal menemukannya. Penyelesaian teorinya ditemukan pada tahun 1922, oleh Friedman dengan menunjukkan persamaan Einstein yang melukiskan alam semesta yang tidak statis, tetapi berkembang.

Alam semesta yang diciptakan Allah SWT. Telah diteliti oleh ilmuan dari berbagai belahan bumi ini. Sejak Morley dan Michelson pada tahun 1905, yang mendorong Einstein melahirkan teori "Relativitasnya". Demikian juga Gamow pada tahun 1952, yang menurutnya suatu ketika seluruh alam ini akan semakin mengecil volumenya akibat ledaknya mendahsyat dari suatu titik dan mengembang sebagaimana diteliti oleh Hubble. Ledakan dahsyat yang memancarkan radiasi sebagai akibat adanya kilatan dari ledakan tersebut. Sebagai akibat dari ledakan itu, ekspansi dari radiasi

10 http://piuii17.blogspot.com/2018/09/hakikat-manusia-dan-masyarakat.html, diakses pada tanggal 19 Februari 2019.

11 Toto Suharto, Filsafat Pendidikan Islam, ( Yogyakarta: Ar-Ruzzma Media, 2006), h. 96-97 
berakibat alam semesta mendingin yang mengubah radiasi menjadi gelombang mikro. $^{12}$

Menurut Abud (1976) bahwa karena keteraturan alam, saling kait mengait dan saling melengkapi antara unsur yang satu dengan unsur lainnya, mengharuskan manusia bekerja sama untuk mewujudkan kehidupan yang sifatnya umum dan mewujudkan manusia yang baik dengan sifatnya yang khusus. Untuk dapat mewujudkan kehidupan yang baik manusia berkewajiban mempelajari, memahami dan mengenal hukum keteraturan alam ini. ${ }^{13}$

Menurut Al-Jurjani dalam kitab Al-Ta Arifat, terma "Alam” segala bahasa berarti segala hal yang menjadi tanda bagi suatu perkara sehingga dapat dikenali, sedangkan secara terminologi berarti segala sesuatu yang maujud ( maufudat) selain Allah, yang dengan ini Allah dapat dikenali, baik dari segi nama maupun dari sifatnya. Segala sesuatu selain Allah, itulah alam secara sederhana. Pengertian ini merupakan pengertian teologis, dalam arti berdasarkan yang dikemukakan oleh para teologi Islam. Adapun secara filosofis, "alam" adalah kumpulan faubar (substansi) yang tersusun secara materi ( maddad) dan bentuk ( shurah) yang ada dilangit dan di bumi. Segala sesuatu yang ada di langit dan di bumi, itulah alam berdasarkan rumusan filsafat. Alam dalam pengertian ini merupakan alam semesta atau jagad raya, yang dalam bahasa Inggris disebut universe.

Alquran tidak secara secara khusus mengungkapkan alam semesta dengan tema "alam" dalam bentuk tunggal, tapi menyebutnya dalam bentuk jamak, yaitu ‘alamin yang diungkapkan sebanyak 73 kali dalam alqur`an. Menurut Muhammad Abduh, orang Arab sepakat bahwa kata 'alamin tidak digunakan untuk merujuk kepada segala sesuatu yang ada seperti alam batu, dan alam tanah, akan tetapi, mereka memakai alamin untuk merujuk kepada setiap makhluk tuhan yang berakal, atau mendekati sifat-sifat berakal, seperti alam manusia, alam hewan, dan alam tumbuhan. Dengan ini, Sirajuddin Zar menawarkan bahwa alqur`an, untuk merujuk alam dalam pengertian alam semesta ( universe) itu, menggunakan kata al-samawat wa al-ardb wa ma bainabuma, yang disebut alquran sebanyak 20 kali. Kata ini mengacu kepada dua alam, dan alam non fisik atau alam gaib, seperti alam malaikat, alam jin, dan alam ruh.

Untuk mempermudah kajian, Abu Al-'Ainain menyebut alam semesta dalam filsafat dengan istilah al-kaun, yang berarti segala sesuatu yang di ciptakan, yang mencangkup nama segala jenis makhluk, baik yang dapat dihitung maupun yang hanya dapat dideskripsikan saja. Al-kaun sebagai wujud makhluk Allah dapat dibagi dalam dua kategori; 'Alam Al-Syahadab yang dapat dikenali melalui panca indera seperti langit

12 Anas Slahudin, Filsafat Pendidikan, (Bandung : CV Pustaka Setia, 2011), h. 100

${ }^{13}$ Maragustam, Filsafat Pendidikan Islam, (Yogyakarta : Kurnia Kalam Semesta, 2014) h. 96 
dan bumi, dan 'Alam Al-Gaib yang hanya dapat dikenali melalui wahyu ilahi, seperti alam malaikat, dan alam jin. Menurut Mulyadhi Kartanegara, alam semesta dalam tinjauan filsafat Islam diciptakan melalui kehendak bebas Tuhan, bukan melalui keniscayaan. Alam semesta diciptakan secara sengaja dan terencana, bukan secara kebetulan. Alam semesta tidak bersifat abadi, tetapi tercipta dalam waktu dengan sebutan titik awal. Alam diciptakan dari tiada meskipun ketiadaan ini tidak harus selalu dipahami dalam arti ketiadaan yang mutlak, tetapi ada sebagai kemungkinan. ${ }^{14}$

2. Pandangan Islam Tentang Alam Semesta

Sebagai asas pendidikan Islam, setiap muslim diarahkan supaya punya pandangan yang jelas tentang hakikat alam semesta baik alam benda maupun alam selain seperti alam sosial. Hakikat alam atau makrokosmos adalah selain tuhan, dan manusia, alam dan kehidupan adalah bagian (mikrokosmos) dari alam makrokosmos. Islam memandang bahwa alam ini diciptakan Allah, yang mempunyai keteraturan dan diciptakan dengan tujuan tertentu dan mulia. ${ }^{15}$ Firman Allah dalam surah Al-Sajadah (32) ayat 4:

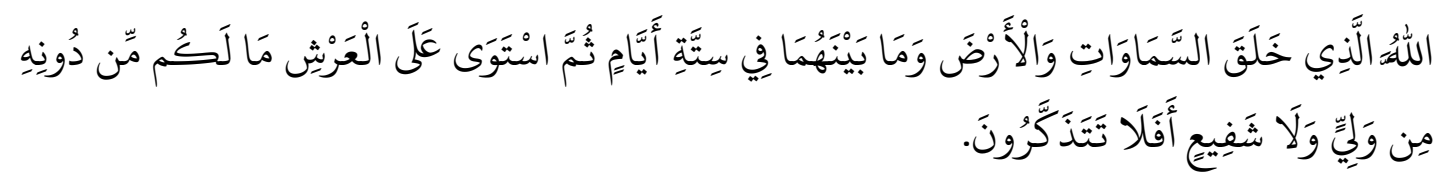

Allah lab yang menciptakan langit dan bumi dan apa yang ada di antara keduanya dalam enam masa, kemudian Dia bersemayam di atas 'Arsy. Tidak ada bagi kamu selain dari pada-Nya seorang penolongpun dan tidak (pula) seorang pemberi syafa'at. Maka apakah kamu tidak memperhatikan.

Kemudian Firman Allah dalam surah al-Zumar (39): 62:

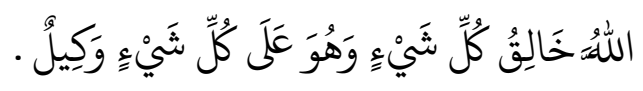

Allah menciptakan segala sesuatu dan Dia memelihara segala sesuatu. ${ }^{16}$

Dari berbagai ayat alqur`an dan berbagai penafsiran para ahli, dalam bukunya, Maragustam berpendapat dalam masalah hakikat alam dalam pandangan Islam:

Pertama, Seluruh alam ini adalah makhluk Allah dan diciptakan dengan punya tujuan tertentu yakni semua menghadap Tuhan. Penciptaan alam atas dasar kebenaran, sama sekali tidak di dorong oleh perbuatan main-main atau sia-sia. Firman Allah dalam surah Al-Ahqaf (46) ayat 3.

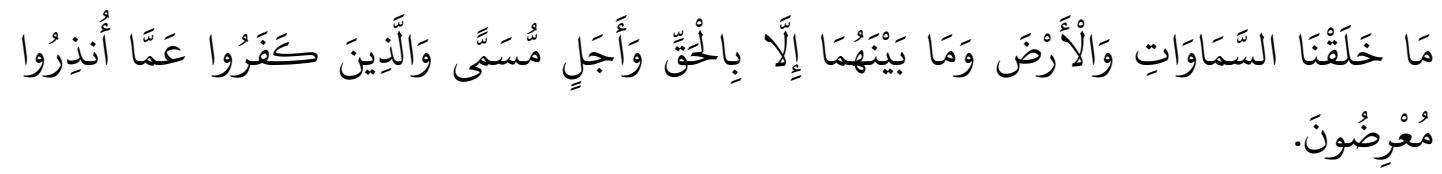

14 Toto Suharto, Filsafat Pendidikan Islam, ( Yogyakarta: Ar-Ruzzma Media, 2006), h. 98-99

${ }^{15}$ Maragustam, Filsafat Pendidikan Islam, ( Yogyakarta : Kurnia Kalam Semesta, 2014) h. 96

16 Departemen Agama RI, Alqur an dan Terjemahannya, (Bandung: PTSygma Examedia Arkanleema) h. 385 
Kami tiada menciptakan langit dan bumi dan apa yang ada antara keduanya melainkan dengan (tujuan) yang benar dan dalam waktu yang ditentukan. Dan orang-orang yang kafir berpaling dari apa yang diperingatkan kepada mereka.

Firman Allah dalam surah al-Dukhan (44) ayat 38-39:

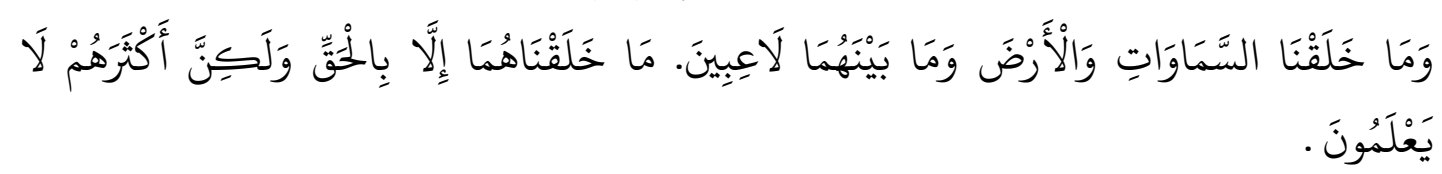

Dan Kami tidak menciptakan langit dan bumi dan apa yang ada antara keduanya dengan bermain-main. Kami tidak menciptakan keduanya melainkan dengan haq, tetapi kebanyakan mereka tidak mengetabui.

Kedua, alam ini diciptakan dengan penuh keteraturan dan alam tunduk kepada sunnatullah (hukum keteraturan) tersebut sesuai ukuran yang telah ditentukannya. Tuhanlah sebagai akhir dari sebab penggerak dan menjalankan sunnatullah itu. Firman Allah dalam surah Fatir (35) ayat 41:

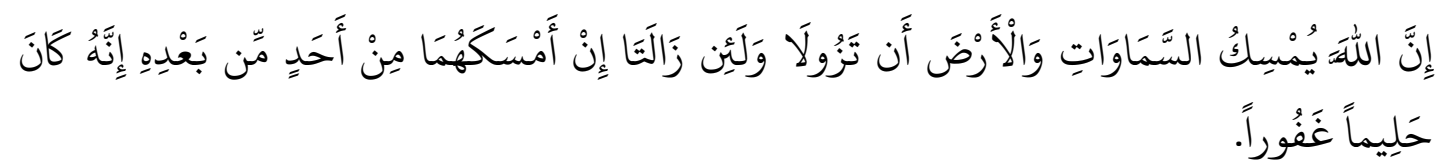

Sesungguhnya Allah menahan langit dan bumi supaya jangan lenyap; dan sungguh jika keduanya akan lenyap tidak ada seorangtun yang dapat menahan keduanya selain Allah. Sesunggubnya Dia adalah Maha Penyantun lagi Maha Pengampun.

Ketiga, kehidupan manusia tunduk kepada sunnatullah kemasyarakatan, Allah telah mengatur sunnah ini bagi kehidupan manusia. Atas dasar ini, maka Allah mengutus para rasul, menyiksa umat, membinasakan sebagian mereka, mengatur ajal dan mengubah keadaan mereka. Firman Allah dalam surah al-Ra`du (13) ayat 10-11:

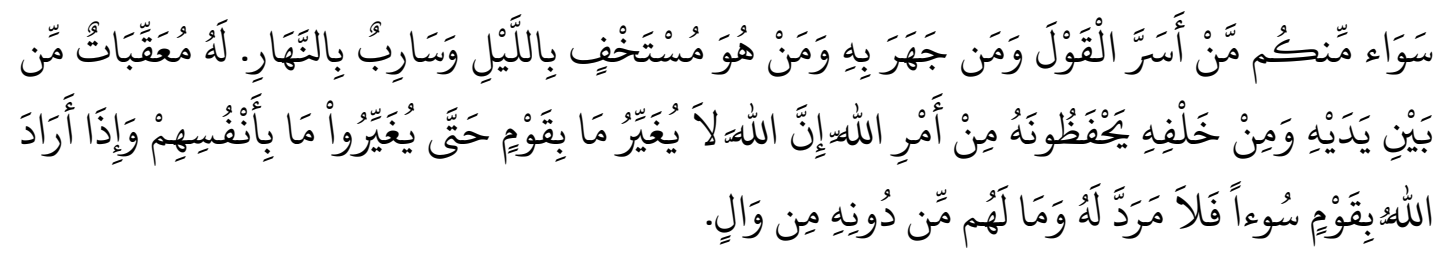

Sama saja (bagi Tuhan), siapa diantaramu yang merahasiakan ucapannya, dan siapa yang berterus-terang dengan ucapan itu, dan siapa yang bersembunyi di malam hari dan yang berjalan (menampakekan diri) di siang hari. Bagi manusia ada malaikat-malaikeat yang selalu mengikutinya bergiliran, di muka dan di belakangnya, mereka menjaganya atas perintah Allah. Sesungguhnya Allah tidak merubah keadaan sesuatu kaum sehingga mereka merubah keadaan yang ada pada diri mereka sendiri. Dan apabila Allab menghendaki keburukan terhadap sesuatu kaum, maka tak ada yang dapat menolaknya; dan sekali-kali tak ada pelindung bagi mereka selain Dia.

Keempat, seluruh alam ini tunduk kepada Allah, baik pengaturan, perintah dan kehendaknya. Firman Allah dalam surah al-Baqarah (2) ayat 116-117: 


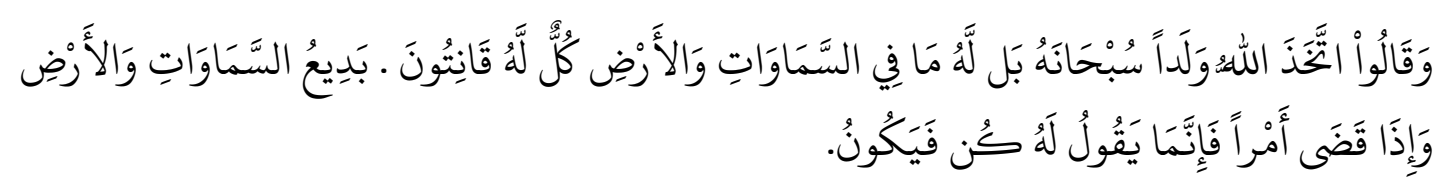

Mereka (orang-orang kafir) berkata: "Allah mempunyai anak". Maha Suci Allah, babkan apa yang ada di langit dan di bumi adalah kepunyaan Allab; semua tunduk kepada-Nya. Allah Pencipta langit dan bumi, dan bila Dia berkehendake (untuk menciptakan) sesuatu, maka (cukuplah) Dia hanya mengatakan kepadanya: "Jadilab!" Lalu jadilah ia.

Kelima, alam ini merupakan nikmat Allah bagi manusia salah satunya yang membedakan Islam dengan yang lainnya adalah bahwa ia menjadikan manusia mampu mempergunakan berbagai daya alam sekitarnya, namun demikian diingatkannya, bahwa manusia mampu menundukkan alam itu dengan izin Allah dan bahwa Allah memang telah menundukkannya baginya. Firman Allah dalam surah al-Baqarah (2) ayat 29:

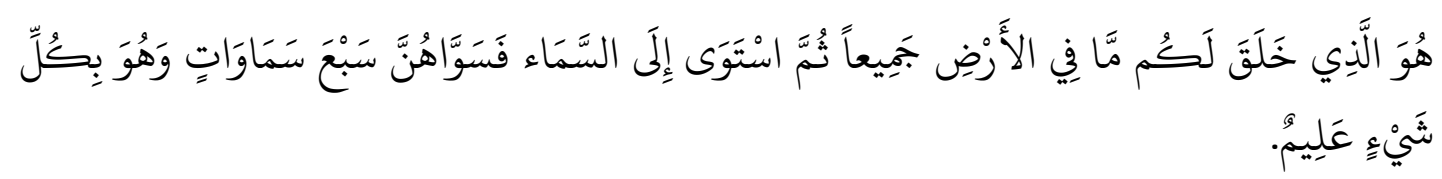

Dialah Allah, yang menjadikan segala yang ada di bumi untuk kamu dan Dia berkehendak (menciptakan) langit, lalu dijadikan-Nya tujub langit. Dan Dia Maha Mengetabui segala sesuatu. ${ }^{17}$

\section{Hakikat Masyarakat}

1. Pengertian Masyarakat

Istilah masyarakat berasal dari kata musyarak yang berasal dari Bahasa Arab yang memiliki arti ikut serta atau berpartisipasi, sedangkan dalam bahasa Inggris disebut Society. Sehingga bisa dikatakan bahwa masyarakat adalah sekumpulan manusia yang berinteraksi dan terjalin erat karena sistem tertentu, tradisi tertentu, konvensi dan hukum tertentu yang sama dan hidup bersama dalam suatu hubungan sosia, dan masyarakat juga merupakan suatu perwujudan kehidupan bersama manusia, atau suatu kelompok manusia yang hidup bersama dalam suatu wilayah dengan tatacara berfikir dan bertindak relatif. Mereka mempunyai kesamaan budaya, wilayah, dan identitas. Dalam masyarakat berlangsung proses kehidupan sosial, proses antar hubungan dan antar aksi. Dengan demikian masyarakat dapat diartikan sebagai wadah atau medan tempat berlangsungnya antar aksi warga masyarakat itu.

Secara umum masyarakat adalah sekumpulan manusia yang bertempat tinggal dalam suatu wilayah dan saling berinteraksi dengan sesama untuk mencapai tujuan. Anggota masyarakat terdiri dari berbagai ragam pendidikan, profesi, keahlian, suku,

${ }^{17}$ Ibid., h.97-98 
bangsa, agama, maupun lapisan sosial sehingga menjadi masyarakat yang majemuk. Secara langsung dan tidak langsung setiap anggota masyarakat tersebut telah menjalin komunikasi mengadakan kerja sama dan saling mempengaruhi dalam rangka mencapai tujuan.

Menurut Syaikh Taqyuddin An-Nabhani, sekelompok manusia dapat dikatakan sebagai sebuah masyarakat apabila memiliki pemikiran, perasaan, serta sistem/aturan yang sama. Dengan kesamaan-kesamaan tersebut, manusia kemudian berinteraksi sesama mereka berdasarkan kemaslahatan. ${ }^{18}$ Menurut Plato tidak membedakan antara pengertian Negara dan masyarakat. Negara tersusun dari individu-individu dan tidak disebutkan kesatuan-kesatuan lebih besar. Negara sama dengan masyarakat. Menurut Aristoteles membuat perbedaan antara Negara dan masyarakat. Negara adalah kumpulan dari unit-unit kemasyarakatn, masyarakat terdiri dari keluarga-keluarga, sedangkan menurut Comte memperluas analisis-analisis masyarakat, dengan menganut suatu pandangan tentang masyarakat sebagai lebih dari suatu agriget (gerombolan) individu-individu (Loren Bagus 2000.)

Dalam Islam alqur`an membahas masyarakat dalam beberapa istilah, diantaranya menggunakan kata Ummah, Qaum, Qabilah, Sya`b, Tha`Ifah atau Jama`ah. Namun dari sekian banyak istilah yang digunakan alqur`an lebih banyak menggunakan istilah ummah. Alqur'an menyebut kata ummah sebanyak 51 kali, sedangkan kata umam sebanyak 13 kali. Pada tulisan ini lebih menfokuskan pembahasan pada kata ummah dengan arti masyarakat. Menurut ahli Syari ati (1989) makna generik ummah memiliki keunggulan.

Kata ummah manusia yang dipakai oleh alqur`an tidaklah berasal dari kata alif, mim, mim tetapi kata tersebut merupakan pinjaman dari bahasa Ibrani yaitu umma, atau dari bahasa arab yaitu ummata (Gibb and Kramers,1960). Bagaimanapun kata umma baik dalam arti apapun mempunyai akar kata alif, mim, mim, dan dari kata umam dan umm. Menurut Jhon Penrince (1971) bahwa kata ummata berarti penduduk, bangsa, ras, kelompok, ketentuan, istilah tertentu waktu dan agama tertentu. Muhammad Ismail Ibrahim mengartikannya dengan kelompok manusia, muallim, seorang yang baik pada semua seginya, agama, tempat dan waktu.

2. Pandangan Islam Tentang Masyarakat

Firman Allah dalam surah al-Hujurat (49) ayat 13:

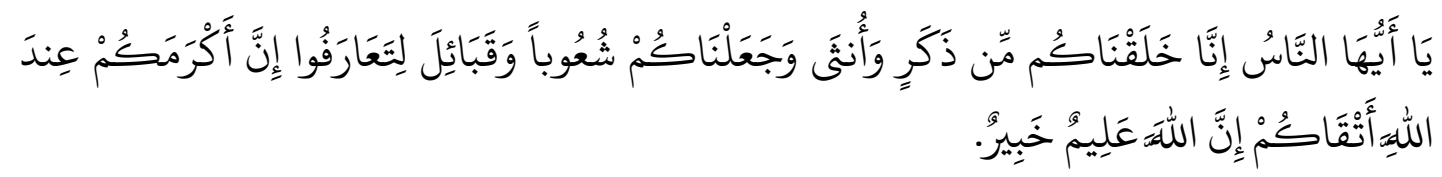

18 http:/ / daviatario.blogspot.com/2014/10/hakekat-masyarakat.html,diakses pada tanggal 19 Februari 2019. 
Hai manusia, sesunggubnya Kami menciptakan kamu dari seorang laki-laki dan seorang perempuan dan menjadikan kamu berbangsa-bangsa dan bersuku-suku supaya kamu saling kenal-mengenal. Sesunggubnya orang yang paling mulia diantara kamu disisi Allah ialah orang yang paling takwa diantara kamu. Sesunggubnya Allab Maha Mengetahui lagi Maha Mengenal.

Dapat disimpulkan bahwa alquran menyebutkan bahwa fitrah manusia itulah adalah juga makhluk sosial dan hidup bermasyarakat merupakan suatu keniscayaan bagi mereka. Di sisi lain juga, ada ayat Al-Qur`an menjelaskan bahwa kecerdasan, kemampuan, status sosial manusia berbeda-beda.

Firman Allah dalam surat al-Zukhruf (43): 32:

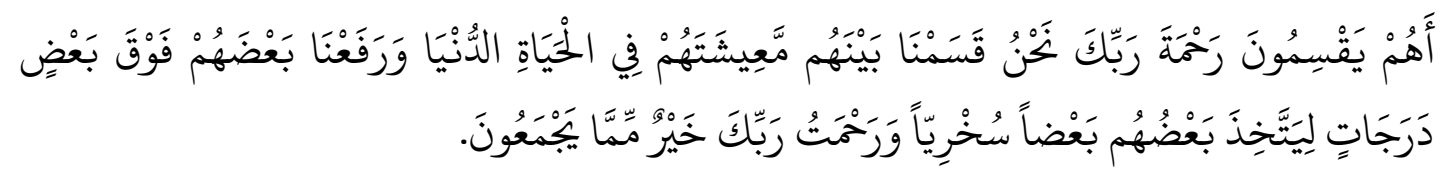

Apakah mereka yang membagi-bagi rahmat Tuhanmu? Kami telah menentukan antara mereka penghidupan mereka dalam kehidupan dunia, dan kami telah meninggikan sebahagian mereka atas sebagian yang lain beberapa derajat, agar sebagian mereka dapat mempergunakan sebagian yang lain. Dan rahmat Tuhanmu lebih baik dari apa yang mereka kumpulkan.

Diuraikan bahwa kehidupan masyarakat merupakan sesuatu yang lahir dari naluri alamiah masing-masing manusia. Maka, hakekat dari masyarakat itu sendiri terletak pada amalnya. Amal sebagai bahan tolak ukur dikemudian hari, sebab dalam suatu riwayat pernah dikatakan manusia yang ketika di hadapkan pada sang pencipta yang dilihat hanyalah amal perbuatannya yang menciptakan keragaman ketaqwaan dari masyarakat itu sendiri. Selaras dengan hal tersebut Al-Qur'an menguraikan dalam Firman Allah dalam surat al-Jatsiyah (45): 28:

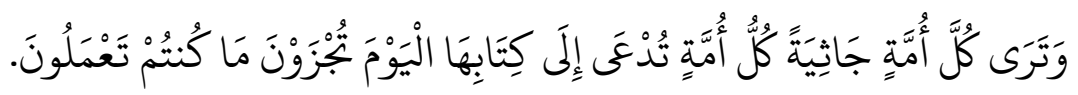

Dan (pada hari itu) kamu lihat tiap-tiap umat berlutut. Tiap-tiap umat dipanggil untuk (melihat) buku catatan amalnya. Pada hari itu kamu diberi balasan terhadap apa yang telah kamu kerjakan.

3. Fungsi Pendidikan Dalam Masyarakat

Menciptakan dan memberdayakan masyarakat yang sesuai dengan tujuan-tujuan menciptakan manusia di muka bumi adalah tujuan dari pendidikan Islam. Tujuan itu ialah menjadikan nilai-nilai Islam sebagai bingkai dalam masyarakat ideal. Lembagalembaga pendidikan sebagai peranan kunci dalam mencapai tujuan sosial yang diharapkan. Pemerintah bersama anggota masyarakat dan orang tua peserta didik telah menyediakan anggaran pendidikan yang diperlukan untuk kemajuan masyarakat dan pembangunan bangsa, untuk mempertahankan nilai-nilai luhur yang berasal dari agama. Pendidikan diharapkan dapat mengembangkan wawasan dan keyakinan peserta 
didik terhadap agama yang dianutnya, ideologi, politik, ekonomi, sosial, budaya dan pertahanan keamanan secara tepat dan benar, sehingga membawa kemajuan pada individu, keluarga, masyarakat dan negara untuk mencapai masyarakat madani yang dijiwai oleh nilai-nilai luhur agama dan budaya. Berbicara tentang fungsi dan peranan pendidikan dalam masyarakat ada bermacam-macam pendapat, dibawah ini disajikan tiga pendapat tentang fungsi pendidikan dalam masyarakat.

Menurut Wiradji bahwa pendidikan sebagai lembaga konservatif mempunyai fungsi-fungsi sebagai berikut: pertama fungsi sosial, kedua fungsi kontrol sosial, ketiga fungsi pelestarian budaya masyarakat, yang ke empat fungsi latihan dan pengembangan tenaga kerja, kelima fungsi seleksi alokasi, keenam fungsi pendidikan dan perubahan sosial, ketujuh fungsi reproduksi budaya, kedelapan fungsi difusi kultural, kesembilan fungsi peningkatan sosial, kesepuluh fungsi moditifikasi sosial.

Dalam mendidik masyarakat yang dijiwai dengan nilai-nilai spiritual keagamaan dan nilai-nilai luhur bangsa harus dimulai dari orang perorang atau kumpulan dari beberapa orang. Dari orang perorang ini akan menginspirasi dalam membentuk keluarga yang bahagia akan memancarkan dan membentuk masyrakat madani. Sesuai dengan UU Sisdiknas nomor 20 tahun 2003 bahwa pendidikan adalah usaha sadar dan terencana untuk mewujudkan suasana belajar dan proses pembelajaran agar peserta didik secara aktif mengembangkan potensi dirinya untuk memiliki kekuatan spiritual keagamaan, pengendalian diri, kepribadian, akhlak mulia, serta keterampilan yang diperlukan dirinya, masyarakat, bangsa dan Negara.

Dari pengertian pendidikan Islam tersebut, maka fungsi pendidikan dalam masyarakat adalah:

Pertama: mengmbangkan, memperbaiki, memimpin, melatih, mengasuh potensi setiap anggota masyarakat (kognitif,efektif, dan psikomotorik) untuk memiliki kekuatan spiritual keagamaan, ilmu, akhlak mulia (karakter kuat positif), dan keterampilan yang diperlukan dalam menjalani hidup bermasyrakat yang kompleks. Secara filosofis bahwa manusia mempunya banyak potensi (fitrah) baik yang bersifat materi seperti fisik,/keterampilan, maupun immateri, seperti hati, rasa, akal, dan lain lain.

Kedua: pewarisan nilai-nilai agama, nilai-nilai budaya, dan norma-norma sosialnilai sosial. Pendidikan tidak hanya transfer ilmu pengetahuan, tetapi juga pengalihan nilai-nilai agama, budaya, dan norma-norma sosial. Pendidikan harus berfungsi mewariskan nilai-nilai agama dan nilai-nilai luhur budaya-tradisi agar masyarakat anggota itu mempunyai spiritual dan makna dalam kehidupan. Maka disamping pendidikan mempunyai fungsi untuk mendidik anggota masyarakat yang beragam, juga harus mewariskan dan melestarikan nilai-nilai Islam dan nilai luhur budaya serta tradisi 
yang masih layak dipertahankan. Sumber nilai budaya dapat dibedakan menjadi tiga bagian yaitu nilai ilahiyah, nilai insaniyan, serta nilai kauniyah.

Ketiga: pendidikan berfungsi sebagai alat kontrol sosial. Pendidikan dapat berfungsi sebagai pelayanan untuk melakukan mekanisme kontrol sosial. Pada fungsi yang pertama dan yang kedua, peserta didik dapat diharapkan sudah memahami hak dan kewajibannya sebagai warga negara dan sebagai khalifah dan nilai-nilai luhur budaya serta tradisi. Dengan kondisi seperti itu peserta didik (anggota masyarakat) mempunyai daya mengontrol atau menahan atau mengurangi sifat-sifat egoisme, kerenggangan sosial, dan disharmoni sosial yang menjadikan dirinya bagian integral dari masyarakat, memiliki tanggung jawab sosial

Keempat: pendidikan berfungsi sebagai alat pemersatu dan pengembangan pribadi dan sosial, fungsi ini sebagai akibat dari fungsi-fungsi sebelumnya. Oleh karena peserta didik sudah memahami dan menghayati nilai-nilai ilahiyah dan insaniyah, nilai-nilai luhur bangsa, dan nilai-nilai multi cultural, maka pendidikan dapat berfungsi sebagai alat pemersatu dan pengembangan pribadi dan pengembangan pribadi dan sosial. ${ }^{19}$

\section{SIMPULAN}

Manusia memiliki eksistensi dalam hidupnya sebagai abdullah dan khalifah sebagai utusan Allah dimuka bumi, disini harus bersentuhan dengan sejarah dengan mengembangkan esensi ingin tahu menjadikan ia bersifat kreatif dengan disemangati dengan nilai-nilai trasendensi. Manusia dengan tuhan memiliki kedudukan sebagai hamba, yang memiliki inspirasi nilai-nilai ketuhanan yang tertanam sebagai pejalan amanah tuhan dimuka bumi. Manusia dengan manusia lainnya memiliki korelasi yang seimbang dan saling bekerja sama dalam rangka memakmurkan bumi. Manusia dengan alam sekitar merupakan sarana untuk meningkatkan pengetahuan dan rasa syukur kita terhadap tuhan dan bertugas menjadikan alam sebagai subyek dalam rangka mendekatkan diri kepada tuhan.

Salah satu dari eksistensi manusia adalah, manusia disebut sebagai makhluk sosial, yang saling membutuhkan dan saling tolong menolong (ta imun). Manusia tidak akan pernah mampu hidup sendiri meskipun manusia hanya untuk memenuhi kehidupan pribadinya. Dalam surah al-Hujurat ayat 13 Allah mengatakan bahwa Allah menciptakan manusia bersuku-suku dan berbangsa-bangsa agar kalian saling kenal mengenal yaitu hidup bermasyarakat dan berdampingan. Maka, hakekat dari masyarakat itu sendiri terletak pada amalnya. Amal sebagai bahan tolak ukur dikemudian hari, sebab dalam suatu riwayat pernah dikatakan manusia yang ketika di hadapkan pada sang pencipta yang dilihat

${ }^{19}$ Maragustam, Filsafat Pendidikan Islam, ( Yogyakarta : Kurnia Kalam Semesta, 2014) h. 89-93 
hanyalah amal perbuatannya yang menciptakan keragaman ketaqwaan dari masyarakat itu sendiri.

\section{DAFTAR PUSTAKA}

Abdullah, Abdurrahman Saleh. Educational Theory; a Qur'anic Outlook Teori-teori Pendidikan Berdasarkan Al-Qur'an, terj. M. Arifin. Jakarta: Rineka Cipta, 2007.

Abu al-Aynain, Ali Khalil. Fasafah al-Tarbiyah al-Islamiyah fi Al-Qur'an al-Karim. Mesir: Dar al-Fikr al-“Arabiyah, 1980.

Ahmadi, Abu. Islam sebagai Paradigma Ilmu Pendidikan. Jogyakarta: Aditya Media, 1992.

al-Banjari, Rachmat Ramadhana. Membaca Kepribadian Manusia seperti Membaca Al-Qur'an. Jogyakarta: DIVA Press, 2008.

al-Jamāli, Muhammad Fādil. FalsafahPendidikan Islam dalam Al-Qur'an. Surabaya: Bina Ilmu, 1986.

Departemen Agama RI. Alquian dan Terjemahannya. Bandung: Sygma Examedia Arkanleema,2014.

http://daviatario.blogspot.com/2014/10/hakekat-masyarakat.html,diakses pada tanggal 19 Februari 2019.

http://piuii17.blogspot.com/2018/09/hakikat-manusia-dan-masyarakat.html, diakses pada tanggal 19 Februari 2019.

Indar, M. Djumberansjah. Filsafat Pendidikan. Surabaya: Karya Abditama, 1994.

Maragustam. Filsafat Pendidikan Islam. Yogyakarta: Kurnia Kalam Semesta, 2014.

Mujib, Abdul dan Jusuf mudzakkir. Ilmu Pendidikan Islam. Jakarta: Prenada Media Group, 2008.

Nata, Abuddin, Filsafat Pendidikan Islam. Jakarta: Gaya Media Pratama, 2005.

Shihab, M. Quraish, Membumikan, Al-Qur'an: Fungsi dan Peran Wabyu dalam Kebidupan Masyarakat. Bandung: Mizan, 1992.

, Logika Agama; Kedudukan Wabyu dan Batas-batas Akal dalam Islam. Jakarta: Lentera Hati, 2005.

Slahudin, Anas. Filsafat Pendidikan. Bandung: Pustaka Setia, 2011.

Suharto, Toto. Filsafat Pendidikan Islam. Yogyakarta: Ar-Ruzzma Media, 2006.

Sutoyo, Anwar. Manusia Dalam Perspektif Alqur an. Yogyakarta: Pustaka Pelajar, 2008.

Tafsir, Ahmad, Ilmu Pendidikan dalam Perspektif Islam Bandung: Remaja Rosdakarya, 2007. 